\title{
Spiritual Resilience and Transactional Analysis Model - Holistic Paradigm for Facing a Global Crisis
}

\section{Angelina Ilievska}

MD, Psychotherapist, Psychiatrist, Private

Practice, Skopje, R. North Macedonia

Naum Ilievski

$\mathrm{PhD}$, Faculty of Psychology, International

Slavic University “Gavrilo R. Derzhavin”,

Sveti Nikole, R. North Macedonia

\section{Abstract}

Faced with the challenge of Covid pandemic, the world will change its existence forever. In such circumstances of the common global crisis, humanity will form new narratives between suffering and survival. From the positioning to this experience, it will depend on whether it will remain a trauma or the deepest inner resources will be activated by building "new personal relationships" on a transpersonal level, and by forming a new alliance, versus the current alienation from nature and the planet. Spiritual resilience is the dimension of the overall mental framework, besides the cognitive, emotional and neurobiological one. This paper postulates the preventive, co-creative, and salutogenic capacity of this essential potential of one's spiritual self even in the most painful and stressful life events. It offers the models based on Christian psychotherapy and Transactional analysis in re-emerging one's inner power in forming adaptive coping mechanism and well-being. Within the TA we operate with the classical approach and two dimensions: intrapersonal and interpersonal and in the domain of spiritual TA- transcedental level regarding the cor self. Christian psychotherapy offers the union of the Holy Eucharist as a pastoral dimension of unity and the individual ascetic discipline through the FCP Method. Expanding the frame of reference - from the narrow anthropocentric to the wider and unlimited theocentric model - such a holistic approach can be successfully applied to all organized forms: family, organizations, and global community, thus creating a strong, aware, and compassionate society.

Keywords: spiritual resilience, transactional analysis, global crisis, adaptive coping, Holy Eucharist

\section{Introduction}


This paper is dedicated to all my colleagues, health professionals, volunteers and professional bodies who bravely and with love give their efforts and contribution in dealing with the Covid pandemic.

\section{To Those who have passed into Eternity may rest in Peace!}

Faced with the challenge of Covid pandemic, the world will change its existence forever. In such circumstances of the common global crisis, humanity will form new narratives between suffering and survival.

From the positioning to this experience it will depend on whether it will remain a trauma or the deepest inner resources will be activated by building "new personal relationships" on a transpersonal level (Ilievski, 2016) and by forming a new alliance, versus the current alienation from nature and the planet "ecological self" (Barrow \& Marshall, 2020).

In such life-threatening circumstances, in addition to the readiness and proactive behavior of each individual in dealing with the consequences, we especially want to emphasize the importance of the deepest personal potentials arising from the spiritual layer of the person determined in its creation but suppressed to oblivion by modern living trends.

The spiritual aspect in general and the spiritual resilience in particular are powerful resources that can enable the survival, existence and reshaping of the existence of humanity even in conditions of bio-psycho-social stress.

\section{The Breaking Point - Crisis and Survival}

When we talk about crisis as a phenomenon, it is most often associated with negative events that result in a negative individual, collective and social impact. In the field of psychology, among the many definitions we have chosen the following, "Crisis is a perception or experience of an event or situation as an intolerable difficulty that exceeds the person's current resources and coping mechanisms" (James \& Gilliland, 2001). The etymological source of the word, according to the ancient, original languages, reflects its higher and essential meaning. We want to point out the Greek

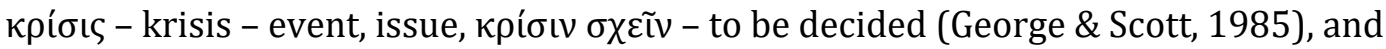
especially the Chinese word, which is composed of two characters "danger" and "opportunity". With this, we are already approaching a new point of view of the crisis as "a testing time" for making new decisions and a source of opportunities. Triggering the complex somato-psychological condition in which a person finds himself during it, only penetrating into the deepest layers of his personality can give him hope and strength to deal with difficult circumstances and catastrophic consequences.

According to the famous creator of Logotherapy, Viktor Frankl, who have survived in the most horrible conditions of a concentration camp, "We all said to each other in camp," he writes, "that there could be no earthly happiness which could compensate for all we had suffered." But it was not the hope of happiness that "gave us courage," 
he writes. It was the "will to meaning" that looked to the future, not to the past (Frankl, 1946).

Every crisis is a breaking point and a new restructuring of life and our position in it.

\section{Spiritual Resilience}

Resilience in modern science is most often associated with the psychological capacities of man. This is why the term psychological resilience is most often described as "the ability to mentally or emotionally cope with a crisis or to return to pre-crisis status quickly" (De Terte \& Stephens, 2014). Building this capacity requires "to be prepared for challenges, crises, and emergencies" (Bergman, 2019).

"Although earlier in the field of psychology, spirituality was largely ignored but resilience research has identifed religion and spirituality as factors of resilience" (Werner, 1984).

Spiritual resilience is contemporary paradigm defined as "the ability to sustain one's sense of self and purpose through a set of beliefs, principles, or values while encountering adversity, stress, and trauma by using internal and external spiritual resources" (Manning et al., 2019).

Spiritual resilience is the dimension of the overall mental framework, besides the cognitive, emotional and neurobiological one. This paper postulates the preventive, co-creative, and salutogenic capacity of this essential potential of one's spiritual self even in the most painful and stressful life events.

Through her personality re-emerges one's inner power in forming adaptive coping mechanism and well-being.

\section{Transactional Analysis Model on Spirituality}

From the very beginning of his work and the creation of the theory of personality and psychotherapeutic modality, Transactional Analysis, the founder Eric Berne pointed to the original religious concepts that served as the basis and inspiration for the various schools of psychotherapy.

Berne's "ancient religious stories" are recommended as prototypes in decoding the complexity of spirituality and religion in human life and psychopathologies. Also, he made his reflections on the problem of "man's essence or Self" (Berne, 1972, p. 438).

Classical Transactional analysis describes the two axes of human existence: intrapersonal and interpersonal in relation with oneself and on the other hand with the world and the others. This operational model is presented trough the concept of ego states. An ego-state, Berne defines "as a consistent pattern of feeling and experience directly related to a corresponding consistent pattern of behavior" (Berne, 1961). 
The axis of transpersonal, as a basis for further development of spiritual transactional analysis, is recognized in the work of transactional analyst Muriel James in the early eighties. It sets the concept of "inner core" as a vehicle for the universal and spiritual self (James, 1981). Thus, the spiritual self became a new reality beyond the rational postulates.

Autonomy and its components - awareness, spontaneity, and intimacy as the highest and ultimate goal in the process of psychological growth and development according to Bern, in their work, Kandathil \& Kandathil (1997) present it as "open door to spirituality" in an attempt to discover the spiritual dimension in addition to the psychological.

\section{The Perspective of Christian Psychotherapy}

Spiritual resilience is the capacity of the spiritually built person, through new personal relationships, with God and the spiritual father, which implies a level of awareness and inner state of spiritual self with hope and faith in the higher providence of Divine for us, life and the world in general (Ilievska \& Ilievski, 2020).

The resilience of the spiritually built person arises primarily as a result of his personal and intimate relationship with God as an inner dimension and from the external level of relationship with the spiritual father, participation in the Holy Eucharist and love communion with church members as a visible reflection of sacred mysteries.

In the process of building spiritual resilience, there are two perspectives, individual and collective, through living as an active member of the Church, and thus two dimensions of spiritual existence (Ilievska, 2020):

- Mystical through the ascethical discipline of FCP method (Ilievski \& Ilievska, 2018) in hesychia "silence of the mind" (Ilievski, 2011);

- Ecclesiastical (with transformed and loving action in the social community).

From this arises the connection and intertwining of spiritual resilience with the category of spiritual identity. "It implies the realization of two aspects, the inner - as a process of metanoia, transformation of the energy of the mind through the ascetic struggle of the mind-and-heart prayer, and outer - transformed acting of the person into the world" (Ilievska, 2020).

Spiritual identity is the basis from which the other components in the domain of human spirituality derive, namely, "Christian identity, on a personal level, is formed in one's spiritual heart through an ascetic-hesychastic struggle, in building personal union with God and - through God - with one's fellowmen. This is the realization of the Christian identity from the aspect of Orthodox Christianity" (Ilievski \& Ilievska, 2020).

\section{Meta-Narratives - Writing Better Stories for Ourselves}


Expanding the frame of reference - from the narrow anthropocentric to the wider and unlimited theocentric model - such a holistic approach can be successfully applied to all organized forms: family, organizations, and global community, thus creating a strong, aware, and compassionate society.

\section{References}

[1] Barrow G. and Marshall H. (April, 2020). Eco-TA, Transactional Analyst, The Journal of the UK Association of TA.

[2] Bergman, M. M. (24 January 2019). Why People in the US South Stay Put in the Face of Climate Change. Retreived from https://www.theguardian.com/environment/2019/jan/24/us-southclimate-change

[3] Berne, E. (1961). Transactional Analysis in Psychotherapy: A Systematic Individual and Social Psychiatry. NY: Grove Press.

https://doi.org/10.1037/11495-000

[4] Berne, E. (1972). What Do You Say After You Say Hello? The Psychology of Human Destiny. New York, NY: Grove Press.

[5] De Terte, I., Stephens, C. (2014). Psychological Resilience of Workers in HighRisk Occupations. Stress and Health, 30 (5), pp. 353-355.

DOI:10.1002/smi.2627.

[6] Frankl, V. (2006). Man's Search for Meaning. Boston, MA: Beacon Press.

[7] Gilliland, B., James, R. (2012). Crisis Intervention Strategies. Boston, MA: Cengage Learning.

[8] Liddell, H. G., Scott, (1996). Greek-English Lexicon. Oxford: Clarendon Press.

[9] Ilievski, N., Ilievska, A. (2017, Sep.-Dec.). Sociological Dimensions of the FCP Method according to Christian Psychotherapy in Coping with Stress and Suffering, European Journal of Social Sciences, Education and Research, 11(1), pp. 93-98.

[10] Ilievska, A. (2020). Ontogenetic Selfregulation (Unpublished paper).

[11] Ilievska, A., Ilievski, N. (2020). Spiritual Resilience and Transactional Analysis Model - Holistic Paradigm for Facing a Global Crisis.

[12] Ilievski, N., Ilievska, A. (2020). The Concept of Peace and Unity from the Perspective of Orthodox Christianity (In press).

[13] James, M. (1981). TA in the 80's: The Inner Core and the Human Spirit. Transactional Analysis Journal, 11(1), pp. 54-65.

[14] Kandathil, G., Kandathil, C. (1997). Autonomy: Open Door to Spirituality. Transactional Analysis Journal, 27(1), 24-29. DOI:

$10.1177 / 036215379702700107$

[15] Manning, L., Ferris, M., Rosario, C. N., Prues, M., \& Bouchard, L. (2019). Spiritual Resilience: Understanding the Protection and Promotion of Well- 
being in the Later Life, Journal of Religion, Spirituality \& Aging, 31(2), pp. 168-186. DOI: 10.1080/15528030.2018.1532859

[16] Митрополит Струмички Наум (2016). Нови личносни односи. Велјуса, Македонија: Манастир Воведение на Пресвета Богородица Елеуса, pp. 181-182.

[17] Митрополит Струмички Наум (2011). Школа за исихазам: основна. Велјуса, Македонија: Манастир Воведение на Пресвета Богородица Елеуса.

[18] Werner, E. E. (1984). Child Care: Kith, Kin and Hired Hand. Baltimore, MD: University Park Press. 